\title{
ANALISIS BEBAN PENCEMARAN DAN INDEKS KUALITAS AIR SUNGAI SILANDAK DAN SUNGAI SIANGKER, SEMARANG
}

\author{
Analysis of pollution Load and Water Quality Index in Silandak and Siangker Rivers, Semarang
}

\section{Tyas Lufiana, Haeruddin ${ }^{*}$ dan Churun Ain}

Program Studi Manajemen Sumberdaya Perairan, Departemen Sumberdaya Akuatik

Fakultas Perikanan dan Ilmu Kelautan, Universitas Diponegoro

J1. Prof. Sudarto,SH, Tembalang, Semarang, Jawa Tengah -50275 , Telp/Fax. +62247474698

Email: tyaslufi@gmail.com

\begin{abstract}
ABSTRAK
Sungai Silandak dan Singker merupakan sungai penting dalam sistem drainase Semarang Barat.Sungai tersebut telah dialiri limbah industri dan limbah domestik yang berasal dari pemukiman warga sekitar. Adanya masukan limbah industri dan domestik akan berpengaruh terhadap kualitas air sungai seperti peningkatan unsur hara yang dapat menyebabkan eutrofikasi. Tujuan dari penelitian ini adalah mengetahui beban pencemaran (TSS, Nitrat, Fosfat) yang akan bermuara ke Teluk Semarang serta mengkaji status pencemaran berdasarkan metode Indeks Kualitas Air pada Sungai Silandak dan Sungai Siangker. Materi yang digunakan dalam penelitian ini adalah contoh air yang diambil pada bagian hulu, tengah dan hilir.Metode penelitian menggunakan metode survei, teknik penentuan lokasi sampling bersifat purposive pada 6 titik lokasi sempling.Contoh air diambil menggunakan metode komposit sebanyak $500 \mathrm{ml}$ pada pagi dan sore hari dengan interval waktu 1 minggu. Hasil yang diperoleh berdasarkan analisis beban pencemaran yang berasal dari Sungai Silandak yaitu TSS 838,31 $\mathrm{mg} /$ detik, nitrat 5,44 mg/detik dan fosfat 5,08 mg/detik dan Sungai Siangker TSS 417,76 mg/detik, nitrat 4,18 $\mathrm{mg} /$ detik dan fosfat 3,42 mg/detik. Kualitas air Sungai Silandak bagian hulu, tegah dan hilir secara berturut-turut termasuk dalam kelas tercemar berat, tercemar sedang dan tercemar sangat berat. Sedangkan kualitas air Sungai Siangker bagian hulu, tengah dan hilir secara berturut-turut termasuk dalam kelas tercemar berat, tercemar berat dan tercemar sangat berat.
\end{abstract}

Kata kunci: Beban Pencemaran, Indeks Kualitas Air, Sungai Silandak, Sungai Siangker

\section{ABSTRACT}

Silandak and Siangker were the important rivers in drainage system on West Semarang. The rivers drained industrial and the domestic waste from around the residential. The industrial and domestic wastes influenced the quality of the waters as the improvement of nutriens that made eutrophication. The purpose of this study was to know the pollution load (TSS, nitrate, phosphate) that flew to bay of Semarang and to review status of pollution from Silandak and Siangker rivers based on the Water Quality Index. Samples of water from Silandak and Siangker rives were taken from the upstream, midstream and downstream. The method used in this study a purposive sampling method to determine on 6 sampling points. Water samples were taken 500 ml by composite in the morning and afternoon in a week. The ammount of pollution load from Silandak river was TSS 838.31 $\mathrm{mg} / \mathrm{second}$, nitrate $5.44 \mathrm{mg} / \mathrm{second}$ and phosphate $5.08 \mathrm{mg} / \mathrm{second}$ and the ammount from Siangker river was TSS $417.76 \mathrm{mg} / \mathrm{second}$, nitrate $4.18 \mathrm{mg} / \mathrm{second}$ and phosphate $3.42 \mathrm{mg} / \mathrm{second}$. The water quality of Silandak river from the upstream, midstream and downstream in a row classified as heavily polluted, moderately polluted and very heavily polluted class while Siangker river from the upstream, midstresm and downstream rin a row classified heavily polluted, heavily polluted and very heavily polluted class.

Key word:Pollution Load, Water Quality Index, Silandak River, Siangker River

*) Penulis Penanggungjawab

\section{PENDAHULUAN}

Sungai Silandak dan Sungai Siangkar merupakan sungai yang terletak di Kecamatan Semarang Barat.Aliran Sungai Silandak dan Sungai Siangker berada di sekitar perkotaan, kawasan industri dan perumahan penduduk. 
Teluk Semarang merupakan perairan yang banyak mendapatkan limpahan massa air, termasuk limbah yang berasal dari aliran Sungai Silandak dan Sungai Siangker. Hal ini terjadi karena perkembangan kegiatan industri, rumah tangga maupun limbah-limbah alami yang menyebabkan terjadinya peningkatan kontaminasi limbah organik maupun anorganik. Berdasarkan data Badan Pusat Statistik Kota Semarang pada tahun 2013 Semarang Barat memiliki luas wilayah 21,74 $\mathrm{km}^{2}$ dengan jumlah penduduk sebanyak 158.668 jiwa dengan kepadatan 7.298. Perkembangan statistik industri besar dan sedang Kota Semarang tahun 2009 terdapat 31 industri besar dan menengah seperti industri kertas lembaran, tahu, rokok kretek, pipa baja, kosmetik dan lainnya yang beroprasi di kawasan Semarang Barat.

Sungai Silandak dan Sungai Siangker merupakan sungai penting dalam sistem drainase Semarang Barat. Hal ini di kemukakan dalam Peraturan Walikota Semarang Nomor 18 Tahun 2014 Tentang Rencana Kerja Pembangunan Daerah Kota Semarang Tahun 2015 bahwa kondisi hidrologi potensi air di Kota Semarang bersumber pada sungai-sungai yang mengalir di Kota Semarang. Letak aliran Sungai Silandak dan Siangker yang berdekatan dengan wilayah perkotaan sangat rawan masuknya limbah domestik dan industri. Limbah domestik yang berasal dari kegiatan rumah tangga, rumah makan dan pariwisata akan berpengaruh terhadap peningkatan unsur hara yang dapat menyebabkan terjadinya peristiwa eutrofikasi. Oleh karena itu parameter nitrat dan fosfat diperlukan sebagai indikator penentuan kualitas lingkungan.Pengaruh limbah industri plastik disekitar aliran Sungai Silandak berpengaruh terhadap kekeruhan perairan karena karakteristik limbah industri mengandung zat padat.Sehingga parameter Total Suspended Solid (TSS) juga diperlukan dalam penentuan kualitas air.Selain itu juga dilakukan pengukuran terhadap parameter pendukung seperti oksigen terlarut, temperatur, kecerahan, kedalaman, arus, debit, $\mathrm{pH}$ dan salinitas.

Berdasarkan kajian yang akan dilakukan penelitian ini diharapkan nantinya diperoleh informasi beban pencemaran yang berasal dari Sungai Silandak dan Siangker yang akan bermuara ke dalam Teluk Semarang dan status pencemaran sungai, sehingga dapat berguna sebagai dasar penentuan kebijakan pengelolaan Sungai Silandak dan Siangker. Tujuan penelitian ini adalah mengetahui beban pencemaran (TSS, Nitrat, Fosfat) dari Sungai Silandak dan Sungai Siangker yang bermuara ke Teluk Semarang serta mengkaji status pencemaranSungai Silandak dan Sungai Siangker berdasarkan metode Indeks Kualitas Air.

\section{MATERI DAN METODE PENELITIAN}

Materi yang digunakan dalam penelitian ini adalah contoh air Sungai Silandak dan Sungai Siangker yang digunakan sebagai analisis beban pencemaran dan indeks kualitas air berdasarkan variabel utama TSS, nitrat, fosfat serta parameter pendukung oksigen terlarut, temperatur, kecerahan, kedalaman, kecepatan arus, debit, salinitas dan pH. Analisis parameter utama TSS berdasarkan Standar Nasional Indonesia Nomor 06-6989.32004, serta untuk pengukuran nitrat dan fosfat menggunakan Handlookprosedur manual HACH 2004.

Penelitian ini mengunakan metode survei, merupakan penyelidikan yang diadakan untuk memperoleh faktafakta dari gejala yang ada dan mencari keterangan secara faktual.Obyek penyelidikan dilakukan di Sungai Silandak dan Siangker untuk mengetahui beban pencemaran (TSS, nitrat dan fosfat) yang bermuara ke Teluk Semarang serta mengetahui kualitas sungai tersebut.Metode survei memberikan evaluasi serta perbandingan terhadap hal serupa dan hasilnya dapat digunakan sebagai pembuatan rencana dan pengambilan keputusan dimasa mendatang (Nazir, 1999).

Pengambilan contoh air mengunakan metode purposive sampling, yaitu teknik penentuan sampel dengan pertimbangan tertentu.Penentuan titik sampling ditentukan berdasarkan penelusuran yang telah dilakukan di sepanjang aliran sungai.Lokasi penelitian terbagi menjadi 3 stasiun yaitu Hulu, Tengah dan Hilir.Contoh air diambil pada pagi dan sore hari berdasarkan perbedaan pasang surut serta waktu keluarnya limbah domestik yang dibuang pada aliran sungai, dengan tiga kali pengulangan pada jarak interval waktu 1 minggu Menurut Standar Nasional Indonesia Nomor 03.7016:2004 perubahan kualitas air yang terus menerus perlu dipertimbangkan dalam penentuan waktu pengambilan contoh pada sumber air. Contoh perlu diambil pada waktu tertentu dan periode yang tetap sehingga data dapat digunakan untuk mengevaluasi perubahan kualitas air. Contoh air diambil pada setiap stasiun menggunakan metode komposit berdasarkan Standar Nasional Indonesia 6989.59:2008 tentang metode pengambilan contoh air limbah, dengan cara contoh air diambil pada tiga titik yaitu bagian pingir, tengah dan pinggir diambil sebanyak $500 \mathrm{ml}$ dengan menggunakan botol sampel.

a. Metode Analisis Data

1. Perhitungan Beban Pencemaran

Beban limbah dihitung berdasarkan rumus menurut Mitsch dan Gooesselink (1993) dalam Marganof et al. (2007) yaitu $B L=Q \times C$, 
Dimana:

$\mathrm{BL}=$ Beban Limbah yang berasal dari sungai (ton/tahun)

$\mathrm{Q}=$ Debit sungai $\left(\mathrm{m}^{3} /\right.$ detik)

$\mathrm{C}=$ Konsentrasi limbah $(\mathrm{mg} / \mathrm{l})$

Mengkonversikan beban limbah ke dalam ton/tahun dikali dengan $10^{-6}$ x 3600 x 24 x 360 .

2. Pehitungan Indeks Kualitas Air

Indeks kualitas air adalah suatu metode untuk menentukan tingkat pencemaran suatu badan perairan dihitung berdasarkan persamaan Altansuukh dan Davva (2011),

IKA $=\frac{\sum C_{i} / P I_{i}}{n}$

Dimana;

IKA = Indeks Kualitas Air

$\mathrm{C}_{\mathrm{i}}=$ konsentrasi peubah mutu air ke-i

$\mathrm{PI}_{\mathrm{i}}=$ baku mutu air yang diperbolehkan untuk peubah mutu air ke-i

$\mathrm{n} \quad=$ jumlah peubah mutu air yang diamati

Baku mutu yang digunakan berdasarkan Peraturan Pemerintah Nomor 82 Tahun 2001 tentang Pengelolaan Kualitas Air dan Pengendalian Pencemaran Air Kelas 2 berdasarkan peruntukannya dapat digunakan untuk sarana dan prasarana rekreasi air, pembudidayaan ikan air tawar, peternakan, dan air untuk mengair pertanaman.dan Baku mutu berdasarkan Keputusan Menteri Lingkungan Hidup Nomor 51 Tahun 2004 tentang Baku Mutu Air Laut untuk Biota Laut. Kemudian hasil perhitungan IKA diintrepetasikan berdasarkan Marganingrum (2012) tersaji dalam Tabel 1.

Tabel 1.Kriteria Nilai WQI (Water Quality Indeks atau Indeks Kualitas Air)

\begin{tabular}{|c|c|c|c|}
\hline \multirow[t]{2}{*}{ Nilai WQI } & \multicolumn{2}{|c|}{ Kualitas air } & \multirow[t]{2}{*}{ Rekomendasi } \\
\hline & Tingkat & Kelas & \\
\hline WQI $\leq 0.30$ & 1 & Sangat bersih & $\begin{array}{l}\text { Tidak diperlukan pengelolaan. Sesuai untuk } \\
\text { berbagai macam penggunaan. }\end{array}$ \\
\hline $0.31 \leq \mathrm{WQI} \leq 0.89$ & 2 & Bersih & $\begin{array}{l}\text { Untuk minum dan pertanian perlu pengelolaan, } \\
\text { untuk perikanan tanpa pengelolaan. }\end{array}$ \\
\hline $0.90 \leq \mathrm{WQI} \leq 2.49$ & 3 & Tercemar ringan & $\begin{array}{l}\text { Tidak sesuai untuk minum dan pertanian, jika } \\
\text { tidak ada pilihan maka perlu dilakukan } \\
\text { pengelolaan untuk dua kebutuhan tersebut. tidak } \\
\text { memerlukan pengelolaan jika digunakan untuk } \\
\text { peternakan, rekreasi dan tujuan olah raga. }\end{array}$ \\
\hline $2.50 \leq \mathrm{WQI} \leq 3.99$ & 4 & Tercemar sedang & $\begin{array}{l}\text { Dapat digunakan untuk irigasi dan keperluan } \\
\text { industri dengan pengelolaan terlebih dahulu. }\end{array}$ \\
\hline $4.00 \leq \mathrm{WQI} \leq 5.99$ & 5 & Tercemar berat & $\begin{array}{l}\text { Hanya dapat digunakan untuk kepentingan } \\
\text { industri berat yang tanpa kontak badan setelah } \\
\text { dilakukan pengelolaan tertentu. }\end{array}$ \\
\hline WQI $\geq 6.00$ & 6 & $\begin{array}{l}\text { Kotor/Tercemar } \\
\text { sangat berat }\end{array}$ & $\begin{array}{l}\text { Tidak sesuai untuk berbagai kebutuhan dan } \\
\text { biaya pengelolaan sangat ekstensif (mahal). }\end{array}$ \\
\hline
\end{tabular}

\section{HASIL DAN PEMBAHASAN}

\section{a. Deskripsi Lokasi Penelitian}

Kota Semarang dibagi menjadi 4 kecamatan, salah satu diantaranya adalah Kecamatan Semarang Barat yang memiliki luas wilayah 21,74 $\mathrm{km}^{2}$. Kecamatan Semarang Barat memiliki 4 subsistem drainase antara lain adalah subsistem Sungai Tugurejo, subsistem Sungai Silandak, subsistem Sungai Siangker dan subsistem Bandar Udara Ahmad Yani.Terdapat 6 titik pengambilan contoh air tersaji dalam Tabel 2.Hasil pengukuran parameter utama TSS,nitrat dan fosfat tersaji dalam Tabel 3 dan 4. 
Tabel 2. Kordinat Pengambilan Contoh Air

\begin{tabular}{|c|c|c|}
\hline Stasiun & Lintang & Bujur \\
\hline AI (Hulu Sungai Silandak) & S 6059'10,63'’ & E 110॰22’31,76”' \\
\hline A2 (Tengah Sungai Silandak) & S $6058^{\prime} 16,11^{\prime \prime}$ & E 110०22'11,39”' \\
\hline A3 (Hilir Sungai Silandak) & S 6057'18,2', & E 110o21'35,3”' \\
\hline A4 (Hulu Sungai Siangker) & S 6058'30,3', & E 110०23'02,2”' \\
\hline A5 (Tengah Sungai Siangker) & S 6058'03,3', & E 110023'02,2" \\
\hline A6 (Hilir Sungai Siangker) & S 6057'25.44', & E $110 \circ 23^{\prime} 1,75^{\prime \prime}$ \\
\hline
\end{tabular}

Tabel 3.TSS, Nitrat $\left(\mathrm{NO}_{3}\right)$ dan Fosfat $\left(\mathrm{PO}_{4}\right)$ Bulan Februari 2016 di Sungai Silandak

\begin{tabular}{|c|c|c|c|c|c|c|c|c|}
\hline \multirow{2}{*}{$\begin{array}{c}\text { Waktu } \\
\text { Sampling }\end{array}$} & \multirow[t]{2}{*}{ Parameter } & \multicolumn{2}{|c|}{ A1 (Hulu)* } & \multicolumn{2}{|c|}{ A2 (Tengah)* } & \multicolumn{2}{|c|}{ A3 (Hilir)** } & \multirow{2}{*}{$\begin{array}{c}\text { Nilai Baku } \\
\text { Mutu }\end{array}$} \\
\hline & & Pagi & Sore & Pagi & Sore & Pagi & Sore & \\
\hline \multirow[t]{3}{*}{$3-2-2016$} & TSS (mg/l) & 120 & 200 & 100 & 160 & 220 & 180 & $* 50$ \\
\hline & Nitrat (mg/l) & 3,50 & 3,30 & 4,30 & 4,30 & 4,80 & 3,10 & $* 10$ \\
\hline & Fosfat $(\mathrm{mg} / \mathrm{l})$ & 5,00 & 6,00 & 5,40 & 2,60 & 2,80 & 3,60 & $* 0,2$ \\
\hline \multirow[t]{3}{*}{$10-2-2016$} & TSS (mg/l) & 180 & 200 & 160 & 180 & 300 & 380 & $* * 20$ \\
\hline & Nitrat (mg/l) & 1,50 & 1,50 & 1,90 & 2,30 & 1,70 & 2,00 & $* * 0,008$ \\
\hline & Fosfat (mg/l) & 2,30 & 2,50 & 1,40 & 1,80 & 1,50 & 2,00 & $* * 0,015$ \\
\hline \multirow[t]{3}{*}{$17-2-2016$} & TSS (mg/l) & 40 & 20 & 40 & 400 & 260 & 460 & \\
\hline & Nitrat (mg/l) & 1,70 & 4,20 & 1,80 & 2,10 & 0,90 & 2,00 & \\
\hline & Fosfat (mg/l) & 1,44 & 2,05 & 1,63 & 1,50 & 4,20 & 0,88 & \\
\hline
\end{tabular}

Tabel 4.TSS, Nitrat $\left(\mathrm{NO}_{3}\right)$ dan Fosfat $\left(\mathrm{PO}_{4}\right)$ Bulan Februari 2016 di Sungai Siangker

\begin{tabular}{|c|c|c|c|c|c|c|c|c|}
\hline \multirow{2}{*}{$\begin{array}{c}\text { Waktu } \\
\text { Sampling }\end{array}$} & \multirow[t]{2}{*}{ Parameter } & \multicolumn{2}{|c|}{ A4 (Hulu)* } & \multicolumn{2}{|c|}{ A5 (Tengah)* } & \multicolumn{2}{|c|}{ A6 (Hilir)** } & \multirow{2}{*}{$\begin{array}{c}\text { Nilai Baku } \\
\text { Mutu }\end{array}$} \\
\hline & & Pagi & Sore & Pagi & Sore & Pagi & Sore & \\
\hline \multirow[t]{3}{*}{$3-2-2016$} & TSS (mg/l) & 200 & 260 & 200 & 200 & 500 & 360 & $* 50$ \\
\hline & Nitrat (mg/l) & 3,40 & 4,30 & 4,80 & 5,00 & 5,20 & 2,90 & $* 10$ \\
\hline & Fosfat (mg/l) & 5,70 & 4,80 & 4,80 & 5,00 & 5,30 & 5,10 & $* 0,2$ \\
\hline \multirow[t]{3}{*}{$10-2-2016$} & TSS (mg/l) & 140 & 200 & 220 & 220 & 280 & 280 & $* * 20$ \\
\hline & Nitrat (mg/l) & 0,60 & 1,20 & 0,60 & 1,10 & 1,30 & 2,80 & $* * 0,008$ \\
\hline & Fosfat (mg/l) & 2,68 & 1,41 & 1,89 & 1,29 & 0,93 & 1,21 & $* * 0,015$ \\
\hline \multirow[t]{3}{*}{$17-2-2016$} & TSS (mg/l) & 60 & 80 & 20 & 120 & 60 & 240 & \\
\hline & Nitrat (mg/l) & 0,70 & 1,30 & 0,90 & 2,00 & 2,90 & 2,70 & \\
\hline & Fosfat (mg/l) & 2,25 & 2,17 & 1,67 & 1,27 & 0,75 & 2,10 & \\
\hline
\end{tabular}

Keterangan:

*Peraturan Pemerintah Nomor 82 Tahun 2001 tentang Pengelolaan Kualitas Air dan Pengendalian Pencemaran Air Kelas 2.

** Keputusan Menteri Lingkungan Hidup Nomor 51 Tahun 2004 tentang Baku Mutu Air Laut untuk Biota Laut.

Kandungan nitrat tertinggi mencapai $5,20 \mathrm{mg} / \mathrm{l}$ dan nilai kandungan fosfat $6,00 \mathrm{mg} / \mathrm{l}$ yang telah melebihi baku mutu dapat di pengaruhi oleh masukan limbah domestik dan industri di sekitar aliran sungai. Menurut Effendi (2003), sumber antropogenik fosfor dan nitrogen adalah limbah industri dan domestik. Menurut Sofyan (2011), hanya dengan konsentrasi rendah $0,5 \mathrm{mg} / \mathrm{l}$ nitrat sudah dapat meningkatkan pertumbuhan tanaman dan algae (ganggang), yang artinya dapat meningkatkan zat organik yang akhirnya akan membusuk.

Nilai nitrat dan fosfat sore hari cenderung lebih tinggi dibandingkan dengan pagi hari. Hal tersebut dapat dipengaruhi oleh proses nitrifikasi yang terjadi pada siang hari karena adanya proses fotosintesis yang dapat meningkatkan kandungan oksigen terlarut. Menurut Badjoeri (2013), proses nitrifikasi salah satu proses yang sangat penting di perairan yang melibatkan proses oksidasi amonia menjadi nitrit dan dilanjutkan dengan oksidasi nitrit menjadi nitrat. Nitrifikasi berlangsung optimal pada kondsi aerobik sehingga memerlukan suplai oksigen yang cukup yaitu antara 0,5 - 0,7 mg/l dan minimal 0,3 - 0,4 mg/l bakteri nitrifikasi masih mampu menjalankan aktivitasnya dan nitrifikasi akan terhenti apabila kandungan oksigen terlarut sampai $0,2 \mathrm{mg} / \mathrm{l}$. Faktor lainnya adalah hasil buangan limbah domestik pada sore hari lebih besar karena pengaruh aktifitas manusia. 
Kandungan oksigen terlarut pada Sungai Silandak dan Siangker memiliki nilai yang bervariasi setiap harinya.Nilai terendah mencapai $1,4 \mathrm{mg} / \mathrm{l}$ dan tertinggi $3,5 \mathrm{mg} / \mathrm{l}$ rendahnya kandungan oksigen terlarut dapat dipengaruhi oleh tingginya suhu pada saat pengambilan contoh air mencapai $33 \circ \mathrm{C}$. Pengaruh tingginya kandungan TSS pada perairan tersebut akan menghalangi sinar matahari masuk dalam perairan sehingga proses fotosintesis akan terganggu dan kandungan oksigen terlarut akan rendah. Menurut Boyd (1988) dalam Effendi (2003), kandungan oksigen terlarut 1,0-5,0 mg/l berpengatuh terhadap kelangsungan hidup ikan yaitu ikan dapat bertahan hidup tetapi pertumbuhannya terganggu.

Berdasarkan hasil pengukuran parameter utama (TSS, nitrat, fosfat) dan debit air selanjutnya dianalisis beban pencemaran pada bagian hilir Sungai Silandak dan Siangker yang masuk ke dalam Teluk Semarang dengan menggunakan metode Mitsch dan Gooesselink (1993). Hasil yang diperoleh adalah tersaji dalam Tabel 5 dan 6.

Tabel 5. Hasil Analisis Beban Pencemaran Bulan Februari di Stasiun A3 (Hilir) Sungai Silandak

\begin{tabular}{ccccc}
\hline $\begin{array}{c}\text { Waktu } \\
\text { Sampling }\end{array}$ & Stasiun A3 (hilir) & $\begin{array}{c}\text { TSS } \\
\text { (mg/detik) }\end{array}$ & $\begin{array}{c}\text { Nitrat } \\
\text { (mg/detik) }\end{array}$ & $\begin{array}{c}\text { Fosfat } \\
\text { (mg/detik) }\end{array}$ \\
\hline $3-2-2016$ & Pagi & 330,66 & 7,21 & 4,20 \\
& Sore & 244,80 & 4,22 & 4,90 \\
\hline $10-2-2016$ & Pagi & $1.101,90$ & 6,24 & 5,51 \\
& Sore & 863,36 & 4,54 & 4,54 \\
\hline $17-2-2016$ & Pagi & 459,42 & 1,59 & 7,42 \\
& Sore & $2.032,74$ & 8,84 & 3,89 \\
\hline & Rata-rata & 838,31 & 5,44 & 5,08
\end{tabular}

Tabel 6. Hasil Analisis Beban Pencemaran Bulan Februari di Stasiun A6 (Hilir) Sungai Siangker

\begin{tabular}{clccc}
\hline $\begin{array}{c}\text { Waktu } \\
\text { Sampling }\end{array}$ & Stasiun A6 (hilir) & $\begin{array}{c}\text { TSS } \\
\text { (mg/detik) }\end{array}$ & $\begin{array}{c}\text { Nitrat } \\
\text { (mg/detik) }\end{array}$ & $\begin{array}{c}\text { Fosfat } \\
\text { (mg/detik) }\end{array}$ \\
\hline $3-2-2016$ & Pagi & 603,00 & 6,27 & 6,39 \\
& Sore & 447,12 & 3,60 & 6,33 \\
\hline \multirow{2}{*}{$10-2-2016$} & Pagi & 679,28 & 3,15 & 2,26 \\
& Sore & 374,92 & 3,75 & 1,62 \\
\hline \multirow{2}{17-2-2016}{} & Pagi & 102,48 & 4,95 & 1,28 \\
& Sore & 299,76 & 3,37 & 2,62 \\
\hline & Rata-rata & 417,76 & 4,18 & 3,42 \\
\hline
\end{tabular}

Beban pencemar berupa Total Suspend Solid (TSS) yang berasal dari Sungai Silandak rata-rata yaitu sebesar 838,31 mg/detik dan dari Sungai Siangker rata-rata yaitu sebesar 417,76 mg/detik. Hal ini dapat dipengaruhi oleh beberapa faktor antara lain adalah jenis sedimen pada bagian hilir Sungai Silandak dan Siangker yaitu pasir, terdapat pipa paralon pembuangan limbah industri plastik di aliran Sungai Silandak juga pada hilir Sungai Siangker terdapat kegiatan reklamasi yang membendung aliran menuju ke laut beberapa faktor tersebut berpengaruh terhadap konsentrasi TSS serta faktor alam lainnya.hal ini di dukung oleh Pujiastuti et al. (2013), bahwa padatan tersuspensi terdiri dari komponen terendapkan, bahan melayang dan komponen tersuspensi koloid. Padatan tersuspensi mengandung bahan anorganik dan bahan organik. Bahan anorganik antara lain berupa liat dan butiran pasir, sedangkan bahan organik berupa sisa-sisa tumbuhan dan padatan biologi lainnya seperti sel alga, bakteri dan sebagainya dapat pula berasal dari kotoran hewan, kotoran manusia, lumpur dan limbah industri.

Nilai rata-rata beban pencemar berupa nitrat yang berasal dari hilir Sungai Silandak sebesar 5,44 mg/detik dan yang berasal dari hilir Sungai Siangker sebesar 4,18 mg/detik yang akan bermuara ke Teluk Semarang. Kandungan nitrat berasal dari beberapa faktor antara lain adalah pengaruh limbah domestik yang masuk kealiran sungai mengingat bahwa pada beberapa stasiun terdapat pipa dan saluran pembuangan limbah dari perumahan langsung selain itu proses oksidasi sempurna senyawa nitrogen di perairan juga dapat meningkatkan kandungan nitrat. Kandungan nitrat yang berlebih dalam perairan akan berdampak terhadap eutrofikasi perairan. Menurut Risamasu (2011), proses pengkayaan zat hara yang berasal dari upwelling, sumber antropogenik dan masukan air sungai menyebabkan peningkatan unsur hara seperti nitrat dan fosfor.Setiap sungai memiliki kemampuan memulihkan diri atau self purification dari beban limbah yang masuk ke perairan.Menurut HH Rump dan $\mathrm{H}$. 
Krist (1992) dalam Sofyan (2011), parameter nitrat sangat penting untuk mengetahui kemampuan self purification suatu perairan dan untuk mengetahui keseimbangan unsur hara di air permukaan dan tanah.

Beban pencemar berupa fosfat yang akan bermuara ke Teluk Semarang yang berasal dari hilir Sungai Silandak memiliki nilai rata-rata sebesar $5,08 \mathrm{mg} /$ detik dan yang berasal dari hilir Sungai Siangker yaitu sebesar 3,42 mg/detik. Adanya pipa dan saluran pembuangan limbah domestik secara langsung seperti pada stasiun A1 dan A5 ke dalam sungai tanpa adanya pengelolaan terlebih dahulu akan berpengaruh terhadap kandungan fosfat. Selain limbah domestik, sumber fosfat dalam perairan adalah dari sedimen.Paytan dan McLaughlin (2007) dalamRisamasu (2011), menyatakan bahwa sedimen merupakan tempat penyimpanan fosfor, umumnya dalam bentuk partikulat yang berikatan dengan oksida besi dan senyawa hidroksida. Senyawa fosfor yang terikat di sedimen dapat mengalami dekomposisi dengan bantuan bakteri maupun melalui proses abiotik menghasilkan senyawa fosfat terlarut yang dapat mengalami difusi kembali ke kolom air. Sehingga kandungan fosfat yang akan bermuara ke Teluk Semarang harus di pantau agar kelangsungan habitat vital seperti estuari dan mangrove tetap terjaga dengan baik.

Berdasarkan penelitian yang dilakukan oleh Sembel (2012), pada estuari Sungai Belau Teluk Lampung dengan nilai debit 3,04 m³/det dikalikan dengan konsentrrasi parameter TSS sebesar 26,66 ml/1, nitrat 0,167 mg/1 dan fosfat $0,071 \mathrm{mg} / \mathrm{l}$. Nilai beban pencemaran yang di peroleh secara berturut-turut adalah TSS $81,07 \mathrm{mg} / \mathrm{detik}$, nitrat $0,508 \mathrm{mg} /$ detik dan fosfat $0,217 \mathrm{mg} /$ detik. Nilai tersebut masih lebih kecil dibandingkan dengan beban pencemaran di hilir Sungai Silandak dan Siangker. Hal ini dipengaruhi oleh konsentrasi kandungan TSS, nitrat dan fosfat pada hilir Sungai Silandak dan Siangker lebih tinggi serta aktivitas di sekitar perairan.

Berdasarkan hasil pengukuran parameter (TSS, nitrat, fosfat dan oksigen terlarut) pada aliran Sungai Silandak dan Siangker.Maka dilakukan analisis Indeks Kualitas Air menggunakan persamaan Altansuuk dan Davva (2011).Hasil yang diperoleh tersaji pada Tabel 7 dan 8.

Tabel 7. Hasil Analisis Indeks Kualitas Air Bulan Februari di Daerah Aliran Sungai Silandak dan Siangker

\begin{tabular}{lllll}
\hline Lokasi & Parameter & 1 (Hulu) & 2 (Tengah) & 3 (Hilir) \\
\hline Sungai Silandak (A) & TSS & 2.53 & 3.47 & 150 \\
& Nitrat & 0.26 & 0.28 & 170.11 \\
& Fosfat & 16.07 & 11.19 & 201.17 \\
& Oksigen Terlarut & 0.67 & 0.52 & 0.52 \\
\cline { 2 - 5 } & Rata-rata IKA & 4.88 & 3.86 & 130.45 \\
\hline
\end{tabular}

Tabel 8.Hasil Analisis Indeks Kualitas Air Bulan Februari di Daerah Aliran Sungai Silandak dan Siangker

\begin{tabular}{lllll}
\hline Lokasi & Parameter & 1 (Hulu) & 2 (Tengah) & 3 (Hilir) \\
\hline Sungai Siangker (B) & TSS & 3.13 & 3.27 & 14.33 \\
& Nitrat & 0.39 & 0.24 & 197.78 \\
& Fosfat & 15.84 & 13.27 & 320.62 \\
& Oksigen Terlarut & 0.46 & 0.59 & 0.49 \\
\cline { 2 - 5 } & Rata-rata IKA & 4.96 & 4.34 & 133.31 \\
\hline
\end{tabular}

Ditinjau berdasarkan stasiun pengambilan contoh air bahwa pada bagian hulu Sungai Silandak dan Siangker termasuk dalam tercemar berat hal ini dapat dipengaruhi oleh kondisi hulu sungai yang banyak terdapat sampah yang tertimbun.Bagian tengah memiliki perbedaan bahwa pada Sungai Silandak termasuk dalam tercemar sedang dan Sungai Siangker tercemar berat.Perbedaan tersebut dipengaruhi oleh kondisi bagian tengah Sungai Silandak lebih bersih dan jauh dari pusat pembuangan limbah sedangkan pada bagian tengah Sungai Siangker tetap pada pembuangan limbah domestik.Bagian hilir Sungai Silandak dan Siangker termasuk dalam tercemar sangat berat hal ini dapat dipengaruhi oleh aktivitas pada kedua hilir sungai tersebut.Bagian hilir Sungai Silandak terdapat aktivitas pariwisata dan banyak sampah yang tertimbun sedangkan pada bagian hilir Sungai Siangker terdapat kegiatan reklamasi dan pemancingan. Sehingga kualitas air dari hulu hingga hilir Sungai Silandak dan Sungai Siangker memiliki kualitas yang hampir sama berdasarkan variabel utama TSS, nitrat, fosfat dan oksigen terlarut.

Berdasarkan penelitian Kementrian Kelautan dan Perikanan dalam kegiatan penyusunan profil pencemaran pesisir kota semarang pada tahun 2015, ada 7 sungai yang bermuara ke Teluk Semarang seperti Sungai Plumbon, Bringin, Pelabuhan, Banjir Kanal Timur, Banjir Kanal Barat, Banger dan Babon. Nilai kekeruhan berkisar dari 
sangat bersih hingga tercemar berat. Indeks Kualitas Air untuk nitrat sebesar 7,6 tergolong tingkat pencemaran 6 yang masuk kelas tercemar sangat berat. Nilai fosfat berkisar 5,33 hingga 40,67 berada dalam tingkat 5-6 kelas tercemar berat hingga sangat berat. Kondisi tersebut hampir sama dibandingkan dengan Sungai Silandak dan Siangker karena dipengaruhi oleh aktivitas disekitar aliran sungai.

Penelitian yang dilakukan oleh Marganingrum (2012), berdasarkan perhitungan nilai IKA Sungai Citarum berkisar antara 0,68-4,00 menggunakan 7 parameter (nitrat, nitrit, fosfat, amonia, DO, BOD dan COD), sehingga kategori Sungai Citarum mulai dari bersih hingga tercemar berat. Apabila dibandingkan dengan kondisi Sungai Silandak dan Siangker dengan 4 parameter (TSS, nitrat, fosfat dan DO) termasuk dalam kategori tercemar sedang hingga tercemar sangat berat.Kategori tersebut lebih tinggi dari Sungai Silandak dan Siangker dikarenakan oleh jumlah parameter dan nilai kandungan parameter nutrien pada Sungai Citarum lebih rendah dibandingkan dengan Sungai Silandak dan Siangker.

\section{KESIMPULAN}

Kesimpulan yang dapat diambil berdasarkan penelitian yang dilakukan di daerah aliran Sungai Silandak dan Sungai Siangker adalah Beban pencemaran yang masuk ke dalam Teluk Semarang yang berasal dari Sungai Silandak yaitu TSS sebesar 838,31 mg/detik, nitrat sebesar 5,44 mg/detik dan fosfat sebesar 5,08 mg/detik. Serta yang berasal dari Sungai Siangker yaitu TSS sebesar 417,76 mg/detik, nitrat sebesar 4,18 mg/detik dan fosfat sebesar 3,42 mg/detik. Berdasarkan perhitungan rata-rata Indek Kualitas Air dengan menggunakan 4 variabel utama TSS, nitrat, fosfat dan oksigen terlarut maka bagian hulu Sungai Silandak dan Siangker termasuk kelas tercemar berat. Bagian tengah Sungai Silandak kelas tercemar sedang sedangkan Sungai Siangker kelas tercemar berat.Bagian hilir sungai Silandak dan Siangker termasuk kelas tercemar sangat berat.

\section{UCAPAN TERIMAKASIH}

Penulis mengucapkan terimakasih kepada Allah SWT yang telah memberikan rahmat dan hidayahnya sehingga penulis dapat menyelesaikan penelitian ini.Terimakasih kepada Ir. Siti Rudiyanti M.Si. Drs. Ign. Boedi Hendarto M.Sc. Ph.D dan Dra Niniek Widyorini MS. sebagai dosen penguji dosen penguji. Serta kepada seluruh pihak yang membantu dalam proses penelitian ini.

\section{DAFTAR PUSTAKA}

Altansuukh, A dan Davva, G. 2011. Application of Index Analysis to Evaluate The Water Quality of The River in Mongolia. Journal of Water Resources and Protection 3: 394-414.

Badjoeri, M. 2013. Distribusi dan Kelimpahan Bakteri Heterotrofik dan Bakteri Nitrifikasi di Danau Loa Kang Kalimantan Timur. Prosending Pertemuan Ilmiah Tahunan MLI I, Cibinong. 65-76.

Badan Pusat Statistik Kota Semarang. 2013. Data Statistik: Kependudukan Kota Semarang.

Bappeda Kota Semarang dan Badan Pusat Statistik Kota Semarang. 2009. Data Statistik: Industri Besar dan Sedang Kota Semarang.

Direktorat Jendral Kelautan Pesisir dan Pulau-Pulau Kecil Satuan Kerja Direktorat Pesisir dan Lautan.2015. Kegiatan Penyusunan Profil Perencanaan Pesisir Kota Semarang. [Laporan Penelitian]. Kementrian Kelautan dan Perikanan Republik Indonesia, 104 hlm.

Effendi. 2003. Telaah Kualitas Air. Kanisius, Yogyakarta, 257 hlm.

HACH. 2004. Spectrophotometer Procedure Manual. Printed in the U.S.A.

Keputusan Mentri Lingkungan Hidup Nomor 51 Tahun 2004 Tentang Baku Mutu Air Laut untuk Biota Laut.

Kordi, K dan M. Ghufran.2005. Pengelolaan Kualitas Air dalam Budidaya Perairan.Rineka Cipta, Jakarta, 210 hlm. 
Marganingrum, D. 2012. Penilaian Mutu Air Sungai dengan Pendekatan Perbedaan Hasil dari Dua Metode Indeks. Buletin Geologi Tata Lingkungan. 23(3): 105-114.

Marganof, L., K. Darusman, E. Riani, dan B. Pramudya. 2007. Analisis Beban Pencemaran, Kapasitas Asimilasi dan Tingkat Pencemaran dalam Upaya Pengendalian Pencemaran Perairan Danau Maninjau. Jurnal Perikanan dan Kelautan. 12(1): 8-14.

Nazir, M. 1999. Metode Penelitian. Ghalia Indonesia, Jakarta, 589 hlm.

Pujiastuti.P., B. Ismail dan Pranoto. 2013. Kualitas dan Beban Pencemaran Perairan Waduk Gajah Mungkur. Jurnal Ekosains. 5(1): 60-75.

Peraturan Pemerintah Republik Indonesia Nomor 82 tahun 2011 Tentang Pengelolaan Kulaitas Air dan Pengendalian Pencemaran Air

Peraturan Walikota Semarang Nomor 18 tahun 2014 Tentang Rencana Kerja Pembangunan Daerah (RKPD) Kota Semarang tahun 2015.

Risamasu, F.J.L., dan H.B. Prayitno. 2011. Kajian Zat Hara Fosfat, Nitrit, Nitrat dan Sillkat di Perairan Kepulauan Matasiri, Kalimantan Selatan. Jurnal Ilmu Kelautan. 16(3): 135-142.

Sembel, L. 2012. Analisis Beban Pencemaran dan Kapasitas Asimilasi di Estuari Sungain Belau Teluk Lampung. Maspari Journal. 4(2): 178-183.

Sofyan I, Usman dan P. Nasution.2011. Studi Kualitas Air untuk Kesehatan Ikan dalam Budidaya Perikanan pada Aliran Sungai Kampak Kiri.Jurnal Perikanan dan Kelautan. 16(1): 64-70.

Standar Nasional Indonesia Nomor 03-7016-2004. Cara Pengambilan Contoh Air dalam Penentuan Kualitas Air Sungai.

Standar Nasional Indonesia Nomor 6989.59:2008. Metode Pengambilan Contoh Air Limbah.

Standar Nasional Indonesia Nomor 06-6989.3-2004. Analisis Total Suspended Solid (TSS). 